\title{
Factors associated with dual use of waterpipe tobacco and cigarettes among adults in Pakistan
}

Mohammed Jawad, ${ }^{1}$ Omara Dogar, ${ }^{2}$ Mona Kanaan, ${ }^{2}$ Jasjit Ahluwalia ${ }^{3}$ and Kamran Siddiqi ${ }^{2}$

${ }^{1}$ Public Health Policy Evaluation Unit, Imperial College London, London, United Kingdom of Great Britain and Northern Ireland. ${ }^{2}$ Department of Health Sciences, University of York, York, United Kingdom. 32Department of Behavioral and Social Sciences, Brown University School of Public Health, Providence, Rhode Island, United States of America. (Correspondence to: Mohammed Jawad: mohammed.jawado6@imperial.ac.uk).

\begin{abstract}
Background: Little is known about dual use of waterpipe tobacco and cigarettes, especially in countries where both are prevalent.

Aims: This study aimed to assess demographic correlates, patterns of use and quit behaviours of waterpipe users in Pakistan who also smoke cigarettes.

Methods: Data were taken from a randomized controlled trial in Pakistan that assessed smoking cessation in 510 adult waterpipe users, stratified on concurrent cigarette use. Logistic regression analysis was done to assess the association between waterpipe tobacco users who also smoke cigarettes (dual use) and their demographic characteristics, smoking history and quit behaviour. Unadjusted odds ratios (OR) and adjusted OR (ORa) and 95\% confidence intervals (CI) were determined.

Results: Dual use was significantly associated with younger age (ORa = 0.36, 95\% CI: 0.19-0.70) and middle-school educational level (11-15 years), versus no formal education, (ORa = 2.01, 95\% CI: 1.15-3.50). Dual use was also associated with smoking less than all day versus all day (defined as continuously for several hours) (ORa $=2.71,95 \%$ : CI 1.73-4.25) and younger age at starting smoking ( $\mathrm{ORa}=0.95,95 \% \mathrm{CI}$ : 0.93-0.98). No association was found between dual use and sex, marital status, duration of smoking, nicotine dependence or quit history.

Conclusion: Waterpipe tobacco users who also smoke cigarettes differ from waterpipe-only users, particularly in demographic characteristics. More research is needed to explore the interaction between these two smoking behaviours. Health promotion and cessation interventions in Pakistan should consider tailoring their approach to account for the unique characteristics of dual waterpipe and cigarette users.
\end{abstract}

Keywords: waterpipe, hookah, shisha, cigarettes, tobacco, Pakistan

Citation: Jawad M; Dogar O; Kanaan M; Ahluwalia J; Siddiqi K. Factors associated with dual use of waterpipe tobacco and cigarettes in adults in Pakistan. East Mediterr Health J. 2020;26(1):47-54. https://doi.org/10.26719/2020.26.1.47

Received: 09/04/19; accepted: 14/07/19

Copyright (c) World Health Organization (WHO) 2020. Open Access. Some rights reserved. This work is available under the CC BY-NC-SA 3.0 IGO license (https://creativecommons.org/licenses/by-nc-sa/3.o/igo).

\section{Introduction}

Waterpipe tobacco use is a centuries old practice in Middle Eastern and South Asian cultures, usually among older males in rural settings (1). The 1990s saw the mass manufacture of flavoured mo'assel (honeyed) waterpipe tobacco, which gained popularity in young people in these regions and spread to North American and European countries $(2,3)$. The Middle East and South Asia have the highest prevalence of waterpipe tobacco use globally. However, according to the Global Youth Tobacco Survey, more than $10 \%$ of schoolchildren were current (past 30 days) users in the Czech Republic, Estonia, Hungary, Latvia, Poland, Romania, Slovakia, Slovenia and Ukraine (4). The 2017 National Youth Tobacco Survey in the United States of America (USA) reported that 3.3\% of high-school students were current waterpipe users (5).

The global rise of waterpipe tobacco smoking, and indeed other non-cigarette tobacco products, has led to an increasing prevalence of dual and polytobacco use, which is a public health concern. Modelling estimates suggest that waterpipe tobacco users who also use cigarettes, smoke both products more frequently and intensely than those who only use one smoking method, thereby exposing them to even more tobacco-related harm (6). A recent systematic review has shown that waterpipe tobacco use predicts later initiation of cigarette smoking (7). In addition, a randomized controlled trial found that some smokers who successfully quit cigarettes were found to then start using waterpipe tobacco (8). Smoking the waterpipe to complement or substitute for other types of tobacco use undermines the public health gains made in tobacco control and requires more investigation.

While much research exploring the reasons for waterpipe tobacco smoking has been done $(9,10)$, few studies have examined dual use of the waterpipe and cigarettes. Cigarette smoking tends to fulfil an individual need that may include coping with stress and satisfying nicotine cravings. Waterpipe tobacco smoking, however, is often described as a pleasurable experience that centres on socializing with others (11). Nearly all research on the differences between dual and waterpipe-only tobacco use has been done in the USA or the United 
Kingdom, and such studies are generally limited to assessing sociodemographic differences (12-17). Only a few studies have assessed patterns of use in more detail. For example, in a small sample of Arab-Americans in the USA, dual waterpipe and cigarette users were found to be more dependent on cigarettes and had more barriers to stopping smoking than cigarette-only users (18). In a large cross-sectional study in the Islamic Republic of Iran, dual waterpipe and cigarette users were more likely to be male and smoke waterpipe tobacco more regularly and in different venues compared with waterpipe-only users (19). This suggests that dual users may respond differently to interventions to control waterpipe use, such as health awareness campaigns and behavioural change techniques, but more research is needed to confirm this assumption in different settings.

To our knowledge, only one study in the Islamic Republic of Iran (19) and another in schoolchildren in Jordan (20) have assessed dual waterpipe tobacco and cigarette use outside of North American and European settings. This is of concern given that both waterpipe tobacco and cigarette use are far more prevalent in the Middle East and South Asia than elsewhere (21). Attitudes to tobacco use, quitting and tobacco control policies may also be different in dual users $(15,16)$. Pakistan, in particular, has a unique waterpipe tobacco context that is largely unexplored and users of waterpipe tobacco in Pakistan are among the most nicotine-dependent globally $(22,23)$. This is the result of a national ban on flavoured mo'assel waterpipe tobacco (24) and the predominant use of an unflavoured and traditional tobacco type that has a high nicotine content (25). Little is known about the patterns of use of unflavoured waterpipe tobacco in areas where it is used and it is unclear whether dual waterpipe tobacco and cigarette users differ from waterpipe-only users in Pakistan. This has implications for the design of tobacco cessation interventions and tobacco control in general.

This study aimed to assess the demographic characteristics, patterns of use and quit behaviour of waterpipe tobacco users in Pakistan who also smoke cigarettes compared to those who only use the waterpipe.

\section{Methods}

\section{Study setting, design and sample}

Data were analysed from participants recruited to a randomized controlled trial in 2016 testing the effect of varenicline on smoking cessation among adult waterpipe smokers in Pakistan (23). The trial protocol and full methods are published elsewhere (26). Briefly, the study recruited adult participants from four districts of Punjab, Pakistan, who smoked waterpipe tobacco daily ( $>25$ days a month) for at least six months. Concurrent cigarette use was employed as a stratifying variable in the study design based on the prevalence of dual use found in a previous smoking cessation trial in Pakistan (22). Recruitment was done in hospitals through distribution of posters and leaflets and in the community through local media and com- munity networks. People were eligible for inclusion in the trial if they intended to quit waterpipe use, but were excluded if they had used pharmacotherapy for tobacco dependence in the past 30 days; were pregnant, lactating or planning to become pregnant; had a medical condition requiring hospitalization; had a previous allergic reaction to varenicline; had a history of heart disease, stroke, epilepsy or mental health conditions; or if they currently used smokeless tobacco or other substances (including alcohol misuse) besides smoked tobacco. Ethical approval for the randomized controlled trial was obtained from the National Bioethics Committee of the Pakistan Medical Research Council and the Research Governance Committee at the University of York, United Kingdom. Informed consent was obtained from each participant.

\section{Measures}

A questionnaire developed on the existing literature (2729) was distributed. This questionnaire recorded demographic data, smoking patterns and history, motivation to quit, withdrawal symptoms and dependency measures (based on the Lebanon Waterpipe Dependence Scale score). The outcome measure of interest for the current study was dual waterpipe and cigarette use. Waterpipe use was defined as smoking at least 25 days a month for at least the past six months, and cigarette use was defined as smoking cigarettes at least once in the past 30 days.

Demographic information recorded included age, sex, marital status, educational level and occupation. Waterpipe smoking history included: daily use (all day, defined as many continuous hours of smoking at a time/ less than all day); length of smoking sessions (smoking without a break) in minutes; smoking duration in years; age at starting smoking; and total dependency score based on the Lebanon Waterpipe Dependence Scale. This tool is adapted from the Fagerstrom Test for Nicotine Dependence and DSM-IV for substance addiction and has been validated in other low- and middle-income countries (29,30). Waterpipe quit history variables included: previous quit attempts (yes/no), and, if yes, the number of previous quit attempts, time since last quit attempt and longest abstinence time.

\section{Statistical analysis}

Data were analysed descriptively using frequency counts and percentages for categorical variables and data and the mean and standard deviation (SD) for continuous variables (or the median and interquartile range if the data were skewed). Demographic characteristics, waterpipe smoking history, waterpipe quit history and quit outcome were cross-tabulated by dual use of waterpipe and cigarettes. We then constructed logistic regression models to test the relationship between dual waterpipe and cigarette use and the independent variables. We checked for collinearity between independent variables by assessing the variance inflation factor, which was less than two for all variables. Model 1 examined associations without adjusting for confounding and presents the unadjusted odds ratios (ORs) and 95\% confidence intervals (95\% CIs). 
Variables that were statistically significant at $P<0.05$ in model 1 were entered into model 2, which was adjusted for all variables in the model. We took an alpha value of less than 0.05 to be statistically significant and presented adjusted odds ratios (ORa) with 95\% CI. All analyses were done using Stata 15.0.

\section{Results}

A total of 510 participants were included in the study; their characteristics are shown in Table 1. The median age of the participants was 48 years, $429(84.1 \%)$ were male (by design of the trial), $440(86.3 \%)$ were married, $187(36.7 \%)$ had no formal education and 195 (38.2\%) worked in agriculture. The median duration of waterpipe smoking was 25 years and median length of smoking sessions was 10 minutes (range 1-79 minutes). As regards daily use, 128 (25.1\%) smoked the waterpipe all day (continuously for hours) as opposed to less than all day. The mean age at starting smoking was 21.9 years. The mean score on the Lebanon Waterpipe Dependence Scale was 19.2 (SD 4.0), indicating a highly nicotine-dependent sample. Previous quit attempts were reported by $95(18.6 \%)$ participants;

\begin{tabular}{|c|c|c|c|}
\hline Variable & Total $(n=510)$ & $\begin{array}{l}\text { Waterpipe-only users } \\
\qquad(n=249)\end{array}$ & $\begin{array}{l}\text { Dual users } \\
(n=261)\end{array}$ \\
\hline \multicolumn{4}{|l|}{ Demographic characteristics } \\
\hline Age, median (IQR) & $48(37-60)$ & $50(40-62)$ & $46(35-57)$ \\
\hline \multicolumn{4}{|l|}{ Sex, no. (\%) } \\
\hline Female & $81(15.9)$ & $41(16.5)$ & $40(15.3)$ \\
\hline Male & $429(84.1)$ & $208(83.5)$ & $221(84.7)$ \\
\hline \multicolumn{4}{|l|}{ Marital status, no. (\%) } \\
\hline Married & $440(86.3)$ & $212(85.1)$ & $228(87.4)$ \\
\hline Other (unmarried, divorced, widowed) & $70(13.7)$ & $37(14.9)$ & $33(12.6)$ \\
\hline \multicolumn{4}{|l|}{ Educational level, no. (\%) } \\
\hline No formal education & $187(36.7)$ & $107(43.0)$ & $80(30.7)$ \\
\hline Primary & $147(28.8)$ & $71(28.5)$ & $76(29.1)$ \\
\hline Middle & $104(20.4)$ & $39(15.7)$ & $65(24.9)$ \\
\hline Secondary or higher & $72(14.1)$ & $32(12.9)$ & $40(15.3)$ \\
\hline \multicolumn{4}{|l|}{ Occupation, no. (\%) } \\
\hline Professional, clerical or sales & $56(11.0)$ & $34(13.7)$ & $22(8.4)$ \\
\hline Skilled or unskilled manual & $61(12.0)$ & $28(11.2)$ & $33(12.6)$ \\
\hline Domestic service & $98(19.2)$ & $53(21.3)$ & $45(17.2)$ \\
\hline Agricultural & $195(38.2)$ & $97(39.0)$ & $98(37.6)$ \\
\hline Daily wage earner & $52(10.2)$ & $21(8.4)$ & $31(11.9)$ \\
\hline Other ${ }^{\mathrm{a}}$ & $48(9.4)$ & $16(6.4)$ & $32(12.3)$ \\
\hline \multicolumn{4}{|l|}{ Waterpipe smoking history } \\
\hline \multicolumn{4}{|l|}{ Daily use, no. (\%) } \\
\hline All day (continuously for several hours) & $128(25.1)$ & $81(32.5)$ & $47(18.0)$ \\
\hline Less than all day & $382(74.9)$ & $168(67.5)$ & $214(82.0)$ \\
\hline Session length, median (IQR) (minutes) & $10(5-10)$ & $10(6-10)$ & $9(5-10)$ \\
\hline Smoking duration, median (IQR) (years) & $25(15-38)$ & $25(15-40)$ & $25(14-35)$ \\
\hline Age started smoking, mean (SD) (years) & $21.9(8.5)$ & $23.6(9.6)$ & $20.4(7.1)$ \\
\hline LWDS score, mean (SD) & $19.2(4.0)$ & $19.4(3.7)$ & $18.9(4.3)$ \\
\hline \multicolumn{4}{|l|}{ Waterpipe quit history } \\
\hline \multicolumn{4}{|l|}{ Previous quit attempt, no. (\%) } \\
\hline No & $415(81.4)$ & $210(84.3)$ & $205(78.5)$ \\
\hline Yes & $95(18.6)$ & $39(15.7)$ & $56(21.5)$ \\
\hline Number of quit attempts, median (IQR) & $1(1-3)$ & $1(1-3)$ & $1(1-3)$ \\
\hline Time since last quit attempt, median (IQR) (years) & $2(1-7)$ & $2(0.7-7)$ & $2(1-5)$ \\
\hline Longest abstinence length, median (IQR) (years) & $0.3(0.3-1)$ & $0.3(0.3-1)$ & $0.3(0.3-1)$ \\
\hline
\end{tabular}

IQR: interquartile range, SD: standard deviation, LWDS: Lebanon Waterpipe Dependence Scale.

${ }^{a}$ Other: other occupations, unemployed, retired or student. 
the median number of quit attempts was 1, the median time since the last quit attempt was 2 years, and the median longest abstinence time was 0.3 years.

Table 1 also shows cross-tabulations between the outcome variable (dual use) and the independent variables (demographic and waterpipe smoking characteristics). Just over half the sample $(261,51.2 \%)$ were dual waterpipe and cigarette users, reflecting the stratification process of the study design. Dual users were about 4 years younger than waterpipe-only users (46 versus 50 years), and had reached a higher educational level and different occupations. Both waterpipe-only and dual users had smoked waterpipe tobacco for 25 years, and had similar lengths of smoking sessions and scores on the Lebanon Waterpipe Dependence Scale (LWDS). More waterpipeonly users reported smoking waterpipe tobacco all day (continuously for hours) compared with dual users (63.3\% versus $36.7 \%$ ). The two groups were broadly similar with respect to waterpipe quit history.

Table 2 shows the results of the logistic regression analyses assessing the association of demographic and waterpipe smoking characteristics with dual use. The unadjusted model (model 1) showed that dual use was significantly associated with younger age, middle-school education (compared with no education) and working as a daily wage earner or in other occupations (including unemployed or retired people or students). We found no statistically significant association between dual use and sex or marital status. Dual use was also associated with smoking less than all day rather than all day (continuously for hours), shorter session lengths and younger age at starting smoking. We found no statistically significant association between waterpipe quit history and dual use.

In the adjusted model (model 2), the association between dual use and age, middle-school education, less than daily use, and younger age at starting smoking remained statistically significant. One main difference between model 2 and model 1 was that all other occupation categories were more likely to report dual use compared with professional, clerical or sales occupations. Another main difference was that the length of waterpipe sessions was not associated with dual use in adjusted model, although the $95 \%$ CIs could not rule out a tentative association $(\mathrm{ORa}=0.73,95 \% \mathrm{CI}$ : 0.52-1.01).

\section{Discussion}

We found that age, educational level, occupation, daily use and age at starting smoking differed significantly between dual and waterpipe-only users in Pakistan. Dual users smoked waterpipe tobacco less intensely each day, and possibly had shorter waterpipe sessions, but showed no difference in dependence or quit measures compared with waterpipe-only users. Our findings provide insight into tobacco use behaviours in waterpipe users in Pakistan, which may help generate hypotheses for future research and approaches for behavioural change interventions to help smokers quit in Pakistan and the Region.

Several factors may explain the findings, although these are tentative and need to be more fully investigated in future research. Firstly, there was a possible socioeconomic gradient with respect to dual use and educational level. This may be because dual use is a more expensive habit to maintain than waterpipe-only use. More educated smokers may have more disposable income to afford dual use. Secondly, a single session of waterpipe tobacco use may last over an hour, and a quarter of our sample reported smoking it all day (continuously for hours). Participants who reported smoking waterpipe tobacco all day were less likely to report dual use, which might reflect the lack of time to also smoke cigarettes or that there was no need for additional nicotine. The very LWDS scores in this study suggests a highly nicotine-dependent sample, regardless of concurrent cigarette use. Thirdly, occupations that were significantly associated with dual use may be less restrictive on any form of smoking at the workplace (e.g. agricultural work, casual work). Professional, clerical or sales occupations may be more likely to be indoor jobs and therefore subject to indoor smoking restrictions. In addition, assembling and smoking waterpipe tobacco indoors may be more difficult given that waterpipes are big and the preparation process is long.

Our findings differ from the literature and may reflect the unique tobacco control context in Pakistan and also our recruitment criteria. Our study suggests that dual users of waterpipe and cigarettes are less intense users of waterpipe tobacco than waterpipe-only users. A cross-sectional study in adults in the Islamic Republic of Iran showed the opposite; $80.3 \%$ of dual waterpipe tobacco and cigarette users smoked waterpipe more than 3-4 times a month (which is considered quite regular) compared with $60.7 \%$ of waterpipe-only users (19). The greater use of waterpipe tobacco among dual users was also reported in schoolchildren in the Middle East (6). Dual or polytobacco users of products other than waterpipe tobacco also report more dependence $(31,32)$. The difference with our findings may reflect the fact the most of the Iranian sample smoked flavoured waterpipe tobacco (most probably mo'assel), which contains less nicotine and is mostly used intermittently, whereas the sample all smoked an unflavoured type of tobacco on at least 25 days a month. The sample was also limited to participants who smoked waterpipe tobacco daily, whereas other studies of dual use had no restrictions on the frequency of waterpipe smoking.

\section{Conclusion}

These findings can be used to tailor more effective health education interventions for dual users of waterpipe tobacco and cigarettes. Cessation services should consider designing programmes that include dual or polytobacco use. Pakistan recently decreased taxes on tobacco (33); given the known effectiveness of this intervention in reducing smoking and benefitting public health, this reduction should be urgently reversed. In view of the distinct characteristics of dual waterpipe and cigarette users compared with waterpipe-only users, how changes in tobacco control policies, such as taxation, affect sociodemo- 


\begin{tabular}{|c|c|c|}
\hline \multirow[t]{2}{*}{ Variable } & Model 1 (unadjusted) & Model 2 (adjusted ${ }^{\mathrm{b}}$ ) \\
\hline & OR $(95 \% \mathrm{CI})$ & $\operatorname{ORa}(95 \% \mathrm{CI})$ \\
\hline \multicolumn{3}{|l|}{ Demographic characteristics } \\
\hline Age & $0.41(0.24-0.72)^{* *}$ & $0.36(0.19-0.70)^{* *}$ \\
\hline \multicolumn{3}{|l|}{ Sex } \\
\hline Female & 1.00 & - \\
\hline Male & $1.09(0.68-1.75)$ & - \\
\hline \multicolumn{3}{|l|}{ Marital status } \\
\hline Married & 1.00 & - \\
\hline Other (unmarried, divorced, widowed) & $0.83(0.50-1.37)$ & - \\
\hline \multicolumn{3}{|l|}{ Educational level } \\
\hline No formal education & 1.00 & 1.00 \\
\hline Primary & $1.43(0.93-2.21)$ & $1.41(0.87-2.27)$ \\
\hline Middle & $2.23(1.36-3.64)^{* *}$ & $2.01(1.15-3.50)^{*}$ \\
\hline Secondary or higher & $1.67(0.97-2.89)$ & $1.73(0.90-3.34)$ \\
\hline \multicolumn{3}{|l|}{ Occupation } \\
\hline Professional, clerical or sales & 1.00 & 1.00 \\
\hline Skilled or unskilled manual & $1.82(0.87-3.80)$ & $2.44(1.06-5.60)^{*}$ \\
\hline Domestic service & $1.31(0.67-2.56)$ & $2.20(1.01-4.78)^{*}$ \\
\hline Agricultural & $1.56(0.85-2.86)$ & $2.32(1.16-4.64)^{*}$ \\
\hline Daily wage earner & $2.28(1.06-4.93)^{*}$ & $3.30(1.39-7.82)^{* *}$ \\
\hline Other & $3.09(1.38-6.91)^{* *}$ & $5.39(2.16-13.41)^{* * *}$ \\
\hline \multicolumn{3}{|l|}{ Waterpipe smoking history } \\
\hline \multicolumn{3}{|l|}{ Daily use } \\
\hline All day (continuously for several hours) & 1.00 & 1.00 \\
\hline Less than all day & $2.20(1.45-3.32)^{* * *}$ & $2.71(1.73-4.25)^{* * *}$ \\
\hline Session length & $0.74(0.54-1.00)^{*}$ & $0.73(0.52-1.01)$ \\
\hline Smoking duration & $0.99(0.79-1.25)$ & - \\
\hline Age at starting smoking & $0.95(0.93-0.97)^{* * *}$ & $0.95(0.93-0.98)^{* * *}$ \\
\hline LWDS score & $0.97(0.93-1.01)$ & - \\
\hline \multicolumn{3}{|l|}{ Waterpipe quit history } \\
\hline \multicolumn{3}{|l|}{ Previous quit attempt } \\
\hline No & 1.00 & - \\
\hline Yes & $1.47(0.94-1.31)$ & - \\
\hline Number of quit attempts & $1.03(0.54-1.95)$ & - \\
\hline Time since last quit attempt (years) & $0.98(0.72-1.34)$ & - \\
\hline Longest abstinence length (years) & $0.98(0.52-1.84)$ & - \\
\hline
\end{tabular}

LWDS: Lebanon Waterpipe Dependence Scale, OR: odds ratio, CI: confidence interval.

${ }^{*} \mathrm{P}<0.05,{ }^{* *} \mathrm{P}<0.01,{ }^{* * *} \mathrm{P}<0.001$.

aOther occupations, unemployed, retired or student.

${ }^{b}$ Adjusted for all variables in the model.

graphic inequalities in waterpipe tobacco use, needs to be understood. Policy-makers should be mindful of possible substitution of products so any tax increases should be simultaneous and comparable across waterpipe tobacco and cigarettes (34). Public awareness activities on the harmful effects of waterpipe tobacco smoking are also urgently needed to change the attitudes and beliefs about this form of smoking and reduce motivation to use it.
This study is one of the first to examine dual waterpipe tobacco and cigarette use in Pakistan, an area where the use of waterpipe tobacco is prevalent and traditional. Future research should explore the age at starting to use both products and the reasons for doing this, knowledge of the health effects of waterpipe tobacco smoking and the specific barriers to quitting. The main limitation of this study is that the results are 
not generalizable, since it was a relatively healthy sample of waterpipe smokers who wanted to quit smoking and was geographically restricted to Punjab. Other forms of tobacco use were excluded; there are likely to be many polytobacco users in Pakistan who may also have distinct sociodemographic and tobacco use characteristics. In addition, the trial excluded waterpipe smokers who had no intention of quitting and who may also have distinct sociodemographic and tobacco use characteristics. The trial did not include exclusive cigarette smokers, which meant that a comparison of dual users with this group could not be made. However, a previous study in people with lung disease in Pakistan showed differences in cigarette-only users and dual users. For example, dual users were older and had smoked for longer, and more dual users were female, had higher carbon monoxide levels and had higher nicotine-dependency scores than the cigarette-only smokers (35).

Funding: The study is funded by Pfizer as part of GRAND 2014 (WI194558). Pfizer were not involved in the study design, data collection, analysis and interpretation, or in the writing of the report. The authors had full independence and access to all of the data and can confirm the integrity of the data and accuracy of the analysis.

Competing interests: None declared.

\section{Facteurs associés au double usage du tabac pour pipe à eau et des cigarettes chez les adultes au Pakistan}

\section{Résumé}

Contexte : Les données sur le double usage du tabac pour pipe à eau et des cigarettes sont rares, notamment dans les pays où les deux sont répandus.

Objectif : La présente étude avait pour objectif d'évaluer les corrélats démographiques, les schémas de consommation et les comportements de sevrage des utilisateurs pakistanais de pipe à eau qui fument également des cigarettes.

Méthodes : Les données ont été tirées d'un essai contrôlé randomisé mené au Pakistan qui a évalué le sevrage tabagique chez 510 utilisateurs adultes de pipe à eau, avec stratification sur la consommation simultanée de cigarettes. Une analyse de régression logistique a été réalisée pour évaluer le lien entre les consommateurs de tabac pour pipe à eau qui fument également des cigarettes (double usage) et leurs caractéristiques démographiques, leurs antécédents de tabagisme et leur comportement en matière de sevrage tabagique. Des odds ratios non ajustés (OR) et ajustés (ORa) et des intervalles de confiance à $95 \%$ ont été déterminés.

Résultats : Le double usage était significativement lié à un âge plus jeune (ORa =0,36, IC à 95\%:0,19-0,70) et à un niveau d'éducation correspondant au collège (11-15 ans) par rapport à l'absence d'éducation formelle (ORa = 2,01, IC à 95\%: 1,15-3,50). Le double usage était également associé à une consommation qui ne s'étendait pas sur toute la journée par rapport à une consommation sur toute la journée (définie comme continue pendant plusieurs heures) (ORa = 2,71, IC à $95 \%: 1,73-4,25)$ et à un âge plus jeune au début du tabagisme (ORa $=0,95$, IC à 95\%: 0,93-0,98). Aucun lien n'a été établi entre le double usage et le sexe, l'état matrimonial, la durée du tabagisme, la dépendance nicotinique ou l'historique des sevrages.

Conclusion : Les consommateurs de tabac pour pipe à eau qui fument également des cigarettes se différencient des consommateurs de tabac pour pipe à eau seul, surtout du point de vue des caractéristiques démographiques. Des recherches supplémentaires sont requises pour étudier l'interaction entre ces deux comportements tabagiques. Les approches de promotion de la santé et les interventions en faveur du sevrage tabagique au Pakistan devraient être adaptées en tenant compte des caractéristiques uniques des consommateurs de tabac pour pipe à eau et de cigarettes.

$$
\begin{aligned}
& \text { العوامل المرتبطة بالاستخدام المزدوج لتبغ النرجيلة والسجائر بين البالغين في باكستان } \\
& \text { محمد جو اد، عمارة دوكر،منى كنعان، جاسجيت أهلوو اليا، قمر ان صديقي }
\end{aligned}
$$

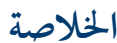

$$
\begin{aligned}
& \text { الخلفية: لا يُعرف سوى قدر ضئيل من المعلومات عن الاستخدام المزدوج لتبخ النرجيلة والسجائر، خاصة في البلدان التي ينتشر فيها تعاطيها. } \\
& \text { الأهداف: هدفت هذه الدر اسة إلى تقييم العو امل السكانية، و أنحاط الاستخدام، وسلو كيات الإقلاع التي ينتهجها متعاطو النرجيلة في باكستان الذين } \\
& \text { يدخنون السجائر أيضاً. }
\end{aligned}
$$

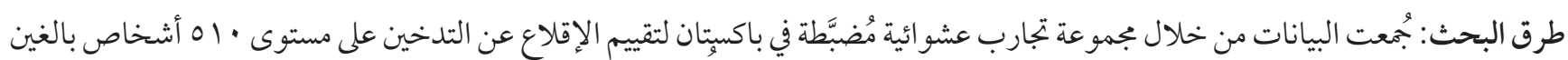

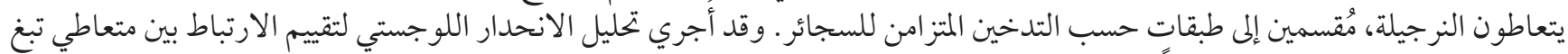

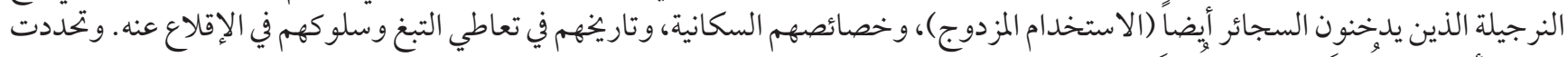

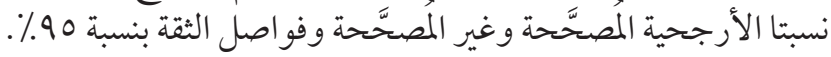




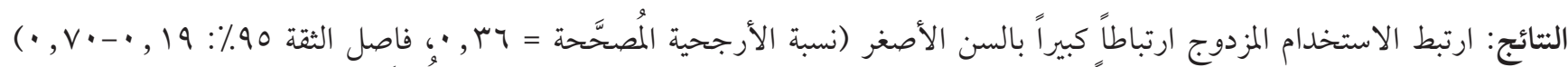

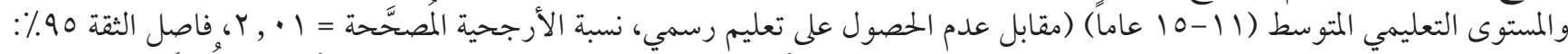

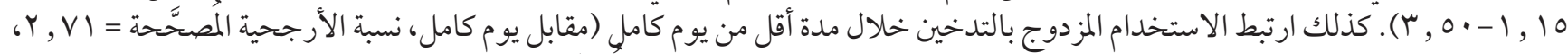

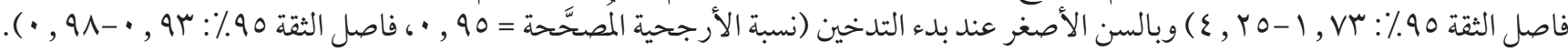

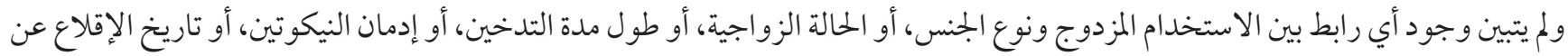
التدخين.

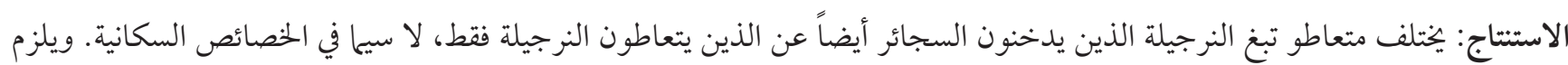

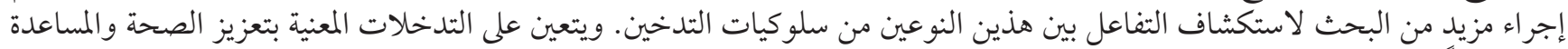

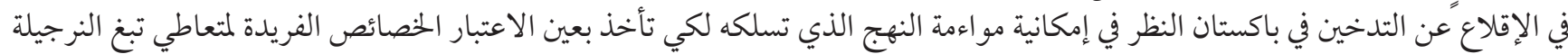
بالتزامن مع تدخين السجائر (الاستخدام المزدوج).

\section{References}

1. Knishkowy B, Amitai Y. Water-pipe (narghile) smoking: an emerging health risk behavior. Pediatrics. 2005;116(1):e113-9.

2. Rastam S, Ward KD, Eissenberg T, Maziak W. Estimating the beginning of the waterpipe epidemic in Syria. BMC Public Health. 2004;4:32. https://doi.org/10.1186/1471-2458-4-32

3. Maziak W. The global epidemic of waterpipe smoking. Addict Behav. 2011;36(1-2):1-5. https://doi.org/10.1016/j.addbeh.2010.08.030

4. Jawad M, Lee JT, Millett C. Waterpipe tobacco smoking prevalence and correlates in 25 Eastern Mediterranean and astern European countries: cross-sectional analysis of the Global Youth Tobacco Survey. Nicotine Tob Res. 2016;18(4):395-402. https://doi. org/10.1093/ntr/ntv101

5. Wang TW, Gentzke A, Sharapova S, Cullen KA, Ambrose BK, Jamal A. Tobacco product use among middle and high school students - United States, 2011-2017. MMWR Morb Mortal Wkly Rep. 2018;67(22):629-33. https://doi.org/10.15585/mmwr.mm6722a3

6. Jawad M, Roderick P. Integrating the impact of cigarette and waterpipe tobacco use among adolescents in the Eastern Mediterranean Region: a cross-sectional, population-level model of toxicant exposure. Tob Control. 2017;26(3):323-9. https://doi.org/10.1136/ tobaccocontrol-2015-052777

7. Al Oweini D, Jawad M, Akl EA. The association of waterpipe tobacco smoking with later initiation of cigarette smoking: a systematic review and meta-analysis exploring the gateway theory. Tob Control. 2019. https://doi.org/10.1136/tobaccocontrol-2018-054870

8. Asfar T, Weg MV, Maziak W, Hammal F, Eissenberg T, Ward KD. Outcomes and adherence in Syria's first smoking cessation trial. Am J Health Behav. 2008;32(2):146-56.

9. Akl EA, Ward KD, Bteddini D, Khaliel R, Alexander AC, Lotfi T, et al. The allure of the waterpipe: a narrative review of factors affecting the epidemic rise in waterpipe smoking among young persons globally. Tob Control. 2015;24(Suppl 1): i13-i21. https:// doi.org/10.1136/tobaccocontrol-2014-051906

10. Akl EA, Jawad M, Lam WY, Co CN, Obeid R, Irani J. Motives, beliefs and attitudes towards waterpipe tobacco smoking: a systematic review. Harm Reduct J. 2013;10:12. https://doi.org/10.1186/1477-7517-10-12

11. Hammal F, Mock J, Ward KD, Eissenberg T, Maziak W. A pleasure among friends: how narghile (waterpipe) smoking differs from cigarette smoking in Syria. Tob Control. 2008;17(2):e3. https://doi.org/10.1136/tc.2007.020529

12. Jarrett T, Blosnich J, Tworek C, Horn K. Hookah use among US college students: results from the National College Health Assessment II. Nicotine Tob Res. 2012;14(10):1145-53. https://doi.org/10.1093/ntr/nts003

13. Jawad M, Choaie E, Brose L, Dogar O, Grant A, Jenkinson E, et al. Waterpipe tobacco use in the United Kingdom: a cross-sectional study among university students and stop smoking practitioners. PLoS One. 2016;11(1):e0146799. https://doi.org/10.1371/journal. pone. 0146799

14. Jones BD, Cunningham-Williams RM. Hookah and cigarette smoking among african american college students: implications for campus risk reduction and health promotion efforts. J Am Coll Health. 2016;64(4):309-17. https://doi.org/10.1080/07448481.2016.11 38479

15. Kassem NO, Kassem NO, Jackson SR, Daffa RM, Liles S, Hovell MF. Arab-American hookah smokers: initiation, and pros and cons of hookah use. Am J Health Behav. 2015;39(5):680-97. https://doi.org/10.5993/AJHB.39.5.10

16. Lee YO, Bahreinifar S, Ling PM. Understanding tobacco-related attitudes among college and noncollege young adult hookah and cigarette users. J Am Coll Health. 2014;62(1):10-8. https://doi.org/10.1080/07448481.2013.842171

17. Salloum RG, Thrasher JF, Getz KR, Barnett TE, Asfar T, Maziak W. Patterns of waterpipe tobacco smoking among US young adults, 2013-2014. Am J Prev Med. 2017;52(4):507-12. https://doi.org/10.1016/j.amepre.2016.10.015

18. El-Shahawy O, Haddad L. Correlation between nicotine dependence and barriers to cessation between exclusive cigarette smokers and dual (water pipe) smokers among Arab Americans. Subst Abuse Rehabil. 2015;6:25-32. https://doi.org/10.2147/SAR.S72360

19. Hessami Z, Masjedi MR, Mortaz E, Herdari G, Kazempour-Diazaji M, Sharifi J, et al. Evaluation of dual tobacco smoking (water pipe and cigarettes) and associated factors in adults in Tehran. Tanaffos. 2016;15(3):180-6. 
20. McKelvey KL, Wilcox ML, Madhivanan P, Mazayek F, Khader YS, Maziak W. Time trends of cigarette and waterpipe smoking among a cohort of school children in Irbid, Jordan, 2008-11. Eur J Public Health. 2013;23(5):862-7. https://doi.org/10.1093/eurpub/ ckt140

21. Jawad M, Charide R, Waziry R, Darzi A, Ballout RA, Akl EA. The prevalence and trends of waterpipe tobacco smoking: a systematic review. PLoS One. 2018;13(2):e0192191. https://doi.org/10.1371/journal.pone.0192191

22. Dogar O, Jawad M, Shah SK, Newell JN, Kanaan M, Khan MA, et al. Effect of cessation interventions on hookah smoking: posthoc analysis of a cluster-randomized controlled trial. Nicotine Tob Res. 2014;16(6):682-8. https://doi.org/10.1093/ntr/ntt211

23. Dogar O, Zahid R, Mansoor S, Kanaan M, Ahluwalia JS, Jawad M, et al. Varenicline versus placebo for waterpipe smoking cessation: a double-blind randomized controlled trial. Addiction. 2018;113(12):2290-9. https://doi.org/10.1111/add.14430

24. Zavery A, Qureshi F, Riaz A, Pervez F, Iqbal N, Khan JA. Water Pipe (shisha) Use and Legislation Awareness Against Shisha Smoking Among Medical Students: A study from Karachi, Pakistan. J Community Health. 2017;42(3):461-5. https://doi.org/10.1007/ s10900-016-0277-4

25. Neergaard J, Singh P, Job J, Montogmery S. Waterpipe smoking and nicotine exposure: a review of the current evidence. Nicotine Tob Res. 2007;9(10):987-94. https://doi.org/10.1080/14622200701591591

26. Zahid R, Dogar O, Mansoor S, Khan A, Kanaan M, Jawad M, et al. The efficacy of varenicline in achieving abstinence among waterpipe tobacco smokers - study protocol for a randomized controlled trial. Trials. 2017;18(1)14. https://doi.org/10.1186/s13063016-1761-y

27. Maziak W, Ben Taleb Z, Jawad M, Afifi R, Nakkash, Akl EA, et al. Consensus statement on assessment of waterpipe smoking in epidemiological studies. Tob Control. 2017;26(3):338-43. https://doi.org/10.1136/tobaccocontrol-2016-052958

28. Maziak W, Ward KD, Afifi Soweid RA, Eissenberg T. Standardizing questionnaire items for the assessment of waterpipe tobacco use in epidemiological studies. Public Health. 2005;119(5):400-4. https://doi.org/10.1016/j.puhe.2004.08.002

29. Salameh P, Waked M, Aoun Z. Waterpipe smoking: construction and validation of the Lebanon Waterpipe Dependence Scale (LWDS-11). Nicotine Tob Res. 2008;10(1):149-58. https://doi.org/10.1080/14622200701767753

30. Primack BA, Khabour OF, Alzoubi KH, Switzer GE, Shensa A, Carroll MV, et al. The LWDS-10J: reliability and validity of the Lebanon Waterpipe Dependence Scale among university students in Jordan. Nicotine Tob Res. 2014;16(7):915-22. https://doi. org/10.1093/ntr/ntuoo2

31. Tomar SL, Alpert HR, Connolly GN. Patterns of dual use of cigarettes and smokeless tobacco among US males: findings from national surveys. Tob Control. 2010;19(2):104-9. https://doi.org/10.1136/tc.2009.031070

32. Wetter DW, McClure JB, de Moor C, Cofta-Gunn L, Cummings S, Cincirpini PM et al. Concomitant use of cigarettes and smokeless tobacco: prevalence, correlates, and predictors of tobacco cessation. Prev Med. 2002;34(6):638-48. https://doi.org/10.1006/ pmed.2002.1032

33. Cut in tobacco tax an embarrassment for Pakistan. Dawn. 18 March 2018 (https://www.dawn.com/news/1395933/cut-in-tobacco-tax-an-embarrassment-for-pakistan, accessed 24 October 2019).

34. Jawad M, Jawad S, Waziry RK, Ballout RA, Akl EA. Interventions for waterpipe tobacco smoking prevention and cessation: a systematic review. Sci Rep. 2016;6:25872. https://doi.org/10.1038/srep25872

35. Siddiqi K, Khan A, Ahmad M, Dogar O, Kanaan M, Newell JN, et al. Action to stop smoking in suspected tuberculosis (ASSIST) in Pakistan: a cluster randomized, controlled trial. Ann Intern Med. 2013;158(9):667-75. https://doi.org/10.7326/0003-4819-158-9201305070-00006 